\section{Beware of wolves in sheep's clothing: immune cell plasticity and instability in health and disease}

We read with great interest the article by Watad et al that characterised for the first time $\mathrm{T}$ lymphocytes in normal human enthesis. ${ }^{1}$ The authors demonstrated that entheseal resident $\mathrm{CD}^{+}$and $\mathrm{CD}^{+}{ }^{+} \mathrm{T}$ cells show increased expression of immunomodulatory genes, including interleukin (IL)-10 and transforming growth factor- $\beta$ compared with the circulating counterpart and that on stimulation they acquire the capability to produce tumour necrosis factor (TNF)- $\alpha$ and IL-17. Of note, normal entheseal $\mathrm{T}$ cells do not express FoxP3 as peripheral blood regulatory $\mathrm{T}$ cells (Treg), but its expression can be induced in specific conditions (eg, in the presence of phosphodiesterase type 4 inhibitor).

The plasticity and instability of immune cells in response to the stimuli of the local microenvironment are a highly interesting field of research under investigation in rheumatic and musculoskeletal diseases (RMDs). ${ }^{2}$ The article by Watad et al provides important insights that will help to better understand pathogenic mechanisms underlying the spectrum of spondyloarthritis (SpA). However, in light of data from experimental models and patients with RMDs, including SpA, some aspects should be remarked.

The dawn of regulatory T cells (Treg) dates back in 1990s, ${ }^{3}$ but the understanding that Treg can transdifferentiate into an effector Th17 phenotype ${ }^{4}$ and that Th17 cells can be redirected to acquire regulatory features is recent history. ${ }^{5}$ The balance between phenotypical plasticity and stability of Treg is orchestrated at the molecular level via the action on regulatory sequences, such as enhancers and promoters, of FoxP3, the master transcription factor of Treg. ${ }^{2}$ In rheumatoid arthritis, TNF- $\alpha$ is able to interfere with the phosphorilation of FoxP3 thereby hampering Treg function, and this can be reverted on treatment with TNF- $\alpha$ inhibitors. ${ }^{6}$

TNF- $\alpha$ may also modulate Treg aberrant transdifferentiation providing yet another rationale for its blockade for therapeutic purposes. However, some aspects on this matter need to be fully addressed due to differences between experimental models and humans, along with the peculiar effects of TNF- $\alpha$ signalling, and likely other cytokines through different receptors. ${ }^{7}$ It would be instrumental to clarify whether the capability of normal entheseal $\mathrm{T}$ cells to induce FoxP3 expression may be affected by the concomitant presence of other soluble factors, such as TNF- $\alpha$ in the local microenvironment and whether entheseal $\mathrm{T}$ cells from patients with SpA still own this capability.

On the other hand, immunomodulatory factors like those secreted by umbilical cord mesenchymal stem cells may facilitate the switch of pathogenic Th17 cells into Treg cells, as demonstrated in healthy subjects, primary Sjögren's syndrome (pSS) and experimental type 1 diabetes. ${ }^{89}$

The evidence that also $\mathrm{CD}^{+} \mathrm{T}$ lymphocytes lacking both CD4 and CD8 on the cell surface (double negative, DN) may display either a regulatory or a Th17-like phenotype in health and disease adds another layer of complexity to this matter. ${ }^{1011}$ IL-17-producing DN T cells have been identified in the cutaneous inflammatory infiltrate of experimental models and patients with psoriasis. ${ }^{12-14}$ In inflamed skin, these cells seem to predominantly express the $\alpha \beta$ T-cell receptor (TCR), while in humans, normal and injured enthesis cells expressing the $\gamma \delta$-TCR account for the majority of local IL-17 production. ${ }^{15}$ It would be therefore interesting to dive into the topic of DN T cells in normal human enthesis in order to reinforce and broaden the rationale for their assessment in SpA. It has been postulated that DN T cells may arise from lymphocytes losing surface CD4 or CD8 on chronic activation ${ }^{16}$; hence, low number or even absence of DN $\mathrm{T}$ cells in normal enthesis should not discourage a more detailed assessment of their phenotype and pathogenic role when affected in SpA. In this regard, it is worth mentioning that while being inhibited by corticosteroids in normal subjects, DN T cells display a certain degree of resistance in patients with pSS, and it would be of great relevance to confirm or rule out whether entheseal DN T cells display this feature in light of possible therapeutic purposes in $\mathrm{SpA} .{ }^{10}$

Finally, as recently demonstrated by Wade et al, psoriatic arthritis (PsA) synovial tissue is enriched of exTh17 cells, also known as nonclassical Th1 cells since they are Th17 cells that no longer produce IL-17 but rather IFN- $\gamma .{ }^{17}{ }^{18}$ Whether exTh17 cells can be also found in normal and/or affected enthesis would shed additional light on this complex scenario. Interestingly, also DN T cells may produce IFN- $\gamma$, for instance, in the inflamed skin of psoriasis-like inflammation, thereby suggesting that a Th17-like towards a Th1-like transdifferentiation may occur also within the DN T cell compartment. ${ }^{13}$

In conclusion, we acknowledge that the study by Watad et al represents a major advancement in the understanding of entheseal pathophysiology, and we believe that further research aimed at addressing the above-mentioned open issues will help elucidate SpA pathogenesis and ultimately improve the care of patients with this disease.

\section{Alessia Alunno $\odot$, Onelia Bistoni, Roberto Gerli \\ Rheumatology Unit, Department of Medicine, University of Perugia, Perugia, Italy}

Correspondence to Professor Roberto Gerli, Department of Medicine, University of Perugia, Piazzale Menghini 1, 06129, Perugia, Italy; roberto.gerli@unipg.it

Contributors All authors drafted and approved the final version of the manuscript.

Funding The authors have not declared a specific grant for this research from any funding agency in the public, commercial or not-for-profit sectors.

Competing interests None declared.

Patient and public involvement Patients and/or the public were not involved in the design, conduct, reporting or dissemination plans of this research.

Patient consent for publication Not required.

Provenance and peer review Not commissioned; internally peer reviewed.

(C) Author(s) (or their employer(s)) 2020. No commercial re-use. See rights and permissions. Published by BMJ.

$$
\text { (A) Check for updates }
$$

To cite Alunno A, Bistoni O, Gerli R. Ann Rheum Dis Epub ahead of print: [please include Day Month Year]. doi:10.1136/annrheumdis-2020-218094

Received 23 May 2020

Accepted 26 May 2020

\section{G Linked}

- https://doi.org/10.1136/annrheumdis-2020-218151

Ann Rheum Dis 2020;0:1-2. doi:10.1136/annrheumdis-2020-218094

\section{ORCID iD}

Alessia Alunno http://orcid.org/0000-0003-1105-5640

\section{REFERENCES}

1 Watad A, Rowe H, Russell T, et al. Normal human enthesis harbours conventional CD4+ and CD8+ T cells with regulatory features and inducible IL-17A and TNF expression. Ann Rheum Dis 2020. doi:10.1136/annrheumdis-2020-217309. [Epub ahead of print: 13 May 2020]. 
2 Yang $\mathrm{P}$, Qian F-Y, Zhang M-F, et al. Th17 cell pathogenicity and plasticity in rheumatoid arthritis. I Leukoc Biol 2019;106:1233-40.

3 Sakaguchi S, Sakaguchi N, Asano M, et al. Immunologic self-tolerance maintained by activated T cells expressing IL-2 receptor alpha-chains (CD25). breakdown of a single mechanism of self-tolerance causes various autoimmune diseases. J Immunol 1995;155:1151-64.

4 Hua J, Inomata T, Chen Y, et al. Pathological conversion of regulatory T cells is associated with loss of allotolerance. Sci Rep 2018:8:7059.

5 Esplugues E, Huber S, Gagliani N, et al. Control of Th17 cells occurs in the small intestine. Nature 2011:475:514-8.

6 Nie H, Zheng Y, Li R, et al. Phosphorylation of FOXP3 controls regulatory $T$ cell function and is inhibited by TNF- $\alpha$ in rheumatoid arthritis. Nat Med 2013;19:322-8.

7 Tseng W-Y, Huang Y-S, Clanchy F, et al. TNF receptor 2 signaling prevents DNA methylation at the Foxp3 promoter and prevents pathogenic conversion of regulatory T cells. Proc Natl Acad Sci U S A 2019;116:21666-72.

8 Alunno A, Montanucci $P$, Bistoni 0 , et al. In vitro immunomodulatory effects of microencapsulated umbilical cord Wharton jelly-derived mesenchymal stem cells in primary Sjögren's syndrome. Rheumatology 2015;54:163-8.

9 Montanucci P, Alunno A, Basta G, et al. Restoration of T cell substes of patients with type 1 diabetes mellitus by microencapsulated human umbilical cord Wharton jelly-derived mesenchymal stem cells: an in vitro study. Clin Immunol 2016;163:34-41.
10 Alunno A, Bistoni O, Bartoloni E, et al. II-17-Producing CD4-CD8- T cells are expanded in the peripheral blood, infiltrate salivary glands and are resistant to corticosteroids in patients with primary Sjogren's syndrome. Ann Rheum Dis 2013;72:286-92.

11 Tian D, Yang L, Wang S, et al. Double negative T cells mediate Lag3-dependent antigen-specific protection in allergic asthma. Nat Commun 2019;10:4246.

12 Sherlock JP, Joyce-Shaikh B, Turner SP, et al. II-23 induces spondyloarthropathy by acting on ROR- $\gamma t+C D 3+C D 4-C D 8$ - entheseal resident T cells. Nat Med 2012:18:1069-76.

13 Brandt D, Sergon M, Abraham S, et al. Tcr + CD3 + CD4 - CD8 - effector T cells in psoriasis. Clinical Immunology 2017;181:51-9.

14 Ueyama A, Imura C, Fusamae Y, et al. Potential role of IL-17-producing CD4/CD8 double negative $\alpha \beta$ T cells in psoriatic skin inflammation in a TPA-induced STAT3C transgenic mouse model. J Dermatol Sci 2017:85:27-35.

15 Cuthbert RJ, Watad A, Fragkakis EM, et al. Evidence that tissue resident human enthesis $\gamma \delta \mathrm{T}$-cells can produce IL-17A independently of IL-23R transcript expression. Ann Rheum Dis 2019;78:1559-65.

16 Grishkan IV, Ntranos A, Calabresi PA, Gocke AR, et al. Helper T cells down-regulate CD4 expression upon chronic stimulation giving rise to double-negative T cells. Cell Immunol 2013:284:68-74.

17 Hirota K, Duarte JH, Veldhoen M, et al. Fate mapping of IL-17-producing T cells in inflammatory responses. Nat Immunol 2011;12:255-63.

18 Wade SM, Canavan M, McGarry T, et al. Association of synovial tissue polyfunctional T-cells with DAPSA in psoriatic arthritis. Ann Rheum Dis 2019;78:350-4. 